\title{
A New Method of Printing Multi-Material Textiles by Fused Deposition Modelling (FDM)
} Nova metoda tiskanja tekstilij iz več materialov s pomočjo tehnologije ciljnega nalaganja

\author{
Original Scientific Article/Izvirni znanstveni članek
}

Received/Prispelo 9-2019 • Accepted/Sprejeto 9-2019

\begin{abstract}
$3 \mathrm{D}$ printing is considered to be the key technology for future production processes. It has recently found its way into the field of the textile industry and promises to revolutionise the textile supply chain. It is of particular interest for the production of customised items and other structures which cannot be produced with common techniques. Large apparel companies have already integrated 3D printing into their manufacturing processes to print parts like soles and accessories. However, 3D printed garments that are ready to wear can still not be found. Due to the lack of suitable printing materials, research in 3D printed textiles is still in its initial stage. This research contributes to the development of 3D printed textiles by using Fused Deposition Modelling (FDM). In this study, a new method for printing textile-like surfaces was developed which combines different materials into an interrelated flexible structure. Several textile-like surfaces were designed on this basis and finally applied to a wearable garment. Furthermore, the advantages of 3D printing for the textile supply chain were demonstrated.

Keywords: 3D printing, 3D printed textiles, textile-like structures, multi-material printing, FDM printing, novel structures

\section{Izvleček}

3D tiskanje velja za ključno tehnologijo proizvodnih procesov v prihodnosti. Tudi na področju tekstilne industrije si je že utrla pot, kjer se napovedujejo revolucionarne spremembe tekstilne dobavne verige. Zlasti je zanimiv za izdelavo izdelkov po meri in drugih struktur, ki jih ni mogoče izdelati z običajnimi tehnologijami. Velika oblačilna podjetja so $\checkmark$ svoje proizvodne procese že vključila 3D tiskanje, da bi natisnili dele, kot so podplati in dodatki. Vendar 3D natisnjenih oblačil, ki so primerna za nošenje, še ni na voljo. Zaradi pomanjkanja primernih tiskarskih materialov so raziskave 3D tiskanih tekstilij še v začetni fazi. Ta raziskava prispeva k razvoju 3D tiskanega tekstila z uporabo tehnologije ciljnega nalaganja. V tej raziskavi je bila razvita nova metoda tiskanja tekstilijam podobnih površin, ki združuje različne materiale v medsebojno prožno strukturo. Na tej podlagi je bilo oblikovanih več, tekstilijam podobnih, površin, ki so bile končno nanešene na nosljivo oblačilo. Prikazane so tudi prednosti 3D tiska za tekstilno dobavno verigo. Ključne besede: 3D tisk, 3D tiskani tekstil, tekstilijam podobne strukture, tisk z več materiali, ciljno nalaganje, nove strukture
\end{abstract}

\section{Introduction}

The 3D printing technology is increasingly used in the textile industry. Additive manufacturing is a

Corresponding author/Korespondenčna avtorica:

Rimma Uysal

E-mail:Rimma.uysal@gmail.com

ORCID: 0000-0002-2879-8056 generic term for all manufacturing processes in which material is applied layer by layer to produce three-dimensional objects. 3D printing offers the decisive advantage of customised products, which

Tekstilec, 2019, 62(4), 248-257

DOI: 10.14502/Tekstilec2019.62.248-257 
are accessible to everyone due to the low cost. In addition, 3D printing can reduce complexity in the supply chain and reduce time to market by accelerating prototyping [1]. The creative minds of the textile industry have quickly realised that the potential of $3 \mathrm{D}$ printing lies in the development of new structures that cannot be achieved with common processes. Large apparel companies have already integrated 3D printing into their manufacturing processes. Increasingly more fashion items, e.g. 3D printed soles [2] and accessories [3], can be now purchased in stores. While these products are ready for the market, the development of 3D printed textiles is still in its initial stage. Despite the increased interest in 3D printing in the textile industry, it is surprising that so little research has been conducted to 3D printed textiles. In this field, the researchers are faced with special challenges. The lack of suitable materials and techniques complicates the development of 3D printed textiles. Thus, the development of 3D printed textiles seems to be very difficult, resulting in the same wearing comfort and durability as conventional garments. Past studies have shown that 3D printing is not yet suitable for the reproduction of textile surfaces and that the potential lies in creating novel textile-like structures [4]. Some studies have tried to combine the old and new technology. 3D printing on textile surfaces has been investigated allowing creating new multicomponent textiles and new optical properties $[5,6]$. Here, the adhesion between both materials still remains challenging and has led to further studies to enhance the bonding properties between two different materials [7] due to fabric pre-treatment $[8,9]$. Furthermore, a study where fibrous materials were embedded in the printing process served as an input for this research [10].

This study was focused on creating textile-like surfaces by using the FDM technology and led to the development of a new printing method. The new printing method combines different materials into one structure, similar to that of a conventional textile. Another focus of this study was on creating flexible and wearable textile-like surfaces.

\section{Materials and methods}

To create textile-like surfaces, a new printing method was developed and applied. This method influences the printing behaviour of a 3D printer. Since usually, the settings in the slicer software determine the printing behaviour, detailed sketches were made in this study for each layer of the print model to intend or at least to influence the printing behaviour. The sketches were made in Adobe Illustrator by taking specific units of measurement into account and then processed into $3 \mathrm{D}$ models by using the animation software Blender. Afterwards, the 3D models were scaled and placed in a print position in the CAD software Autodesk Netfabb. Simplify3D was used to slice the STL files. Here, several print settings were made to optimise the print results. The 3D models were printed in the Prototype Development and 3D Print Lab (PD3D) at the University of Central Florida in Orlando. In this study, two FDM printers were used. Models made of two different materials were printed with the 3D printer X400 (German RepRap $\mathrm{GmbH}$, Feldkirchen, Germany). Models made of more than two different materials were printed with the 3D printer CR-10 (Creality3d, Shenzhen, China) in combination with Palette 2 Pro (Mosaic Manufacturing Ltd, Toronto, Canada). For printing, the filaments PLA (Hatchbox 3d, Pomona, CA, USA) and LAY-FOMM 40 (CC-Products, Cologne, Germany) were used. In the last step, the printed models were post-treated. In the continuation, a step-by-step example of the printing method, using various programs, materials and tools is presented.

\subsection{Structure of 3D printed textile-like surfaces}

The printing method is illustrated in the following steps by means of a $10 \mathrm{~cm} \times 10 \mathrm{~cm}$ textile-like surface. This model was printed from two different materials and consists of 11 layers. Layers 2, 4, 6, 8, 9, 10 and 11 represent the elastic basic structure of the model, the last four layers being intended for contact with the skin surface. This basic structure consists of several parallel strands with varying orientation in different layers. The basic structure was printed from the material LAY-FOMM 40. Layers 1, 3,5 and 7 result in the visible surface of the model and consist of many repeating patterns, here polygons, printed from PLA. All layers are coordinated with each other and together form a system of structures (cf. Figure 1A). If a polygon surface is printed on another polygon surface during the printing process, the two join through the thermoplastic process and enclose the strands in-between (cf. Figure 1B). The strands connect the polygons and result in a coherent structure (cf. Figure 1C) in which both materials cannot be separated from each other. 

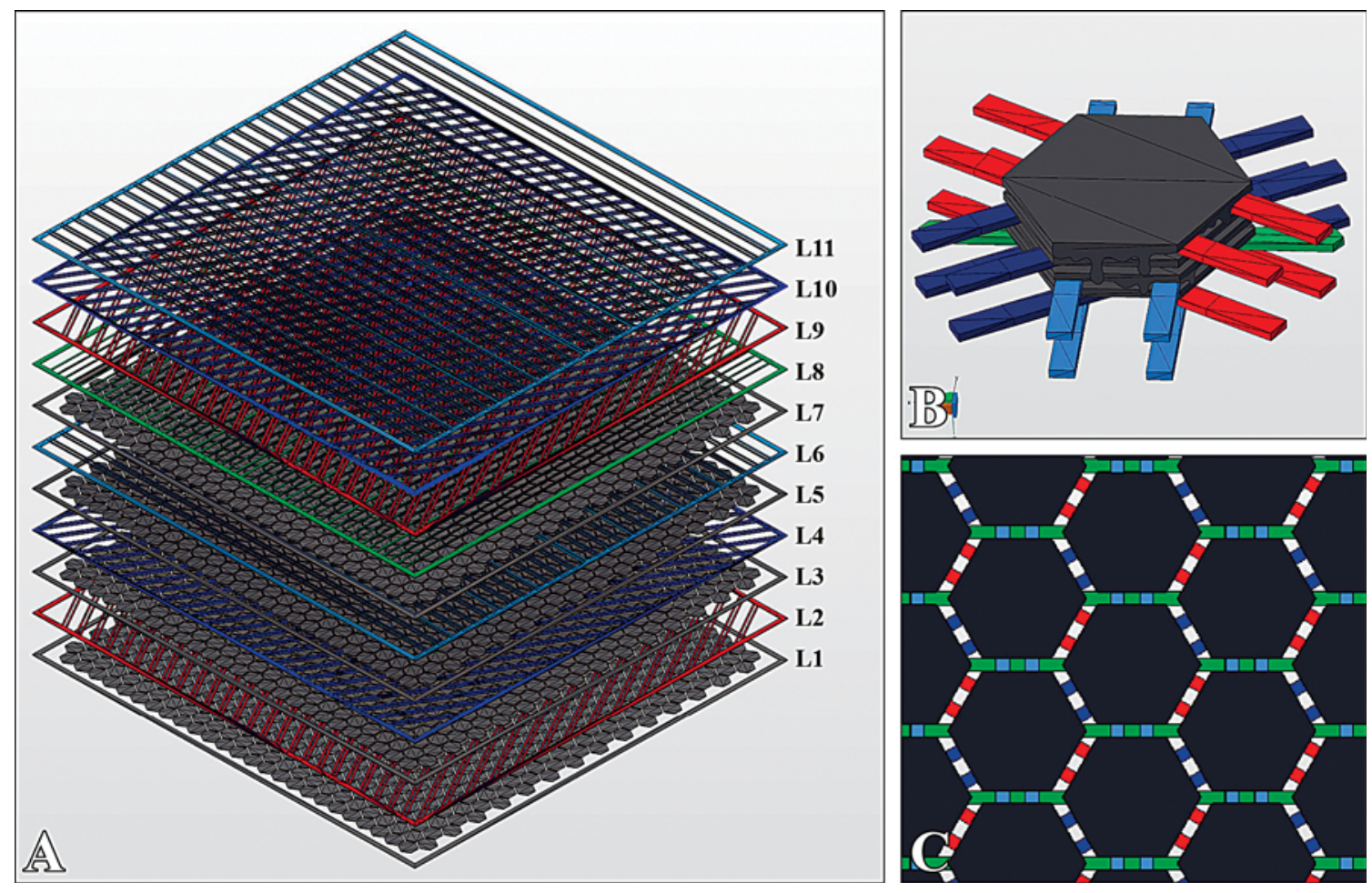

Figure 1: Illustration of textile-like surface in Netfabb: A) structure of layers, B) connected polygons through thermoplastic process, C) coherent structure

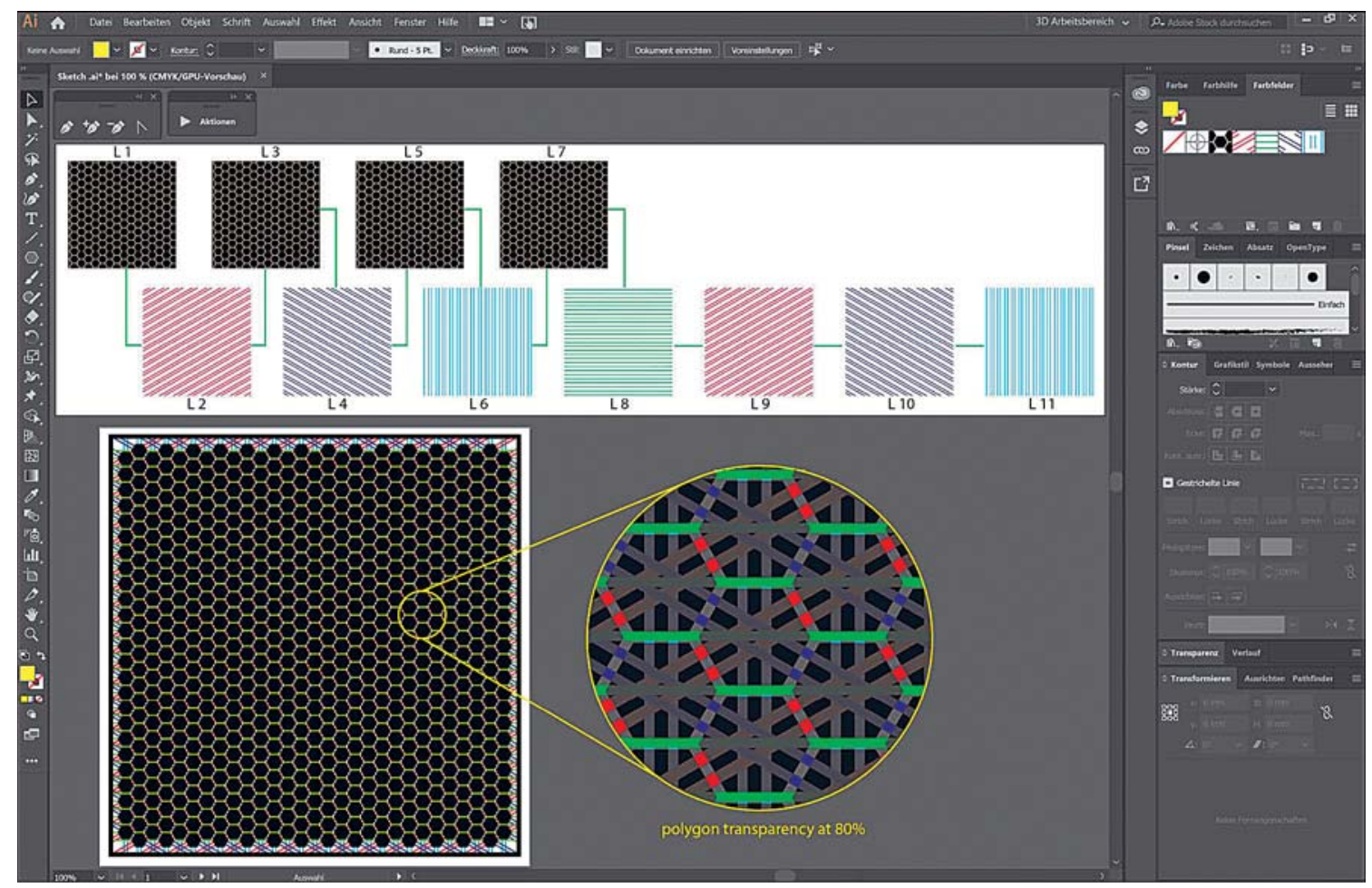

Figure 2: Sketch in Adobe Illustrator 


\subsection{Preparation of sketch}

The sketches were created with the vector graphics editor Adobe Illustrator CC 2019. The creation of the sketch for this printing method is very detailed, each layer has its own sketch. In the end, the $10 \mathrm{~cm} \times 10 \mathrm{~cm}$ model has over 2,000 individual elements. To simplify the drawing, Illustrator patterns were created [11]. This seamless repeating pattern can be applied to any graphic. By creating the patterns, certain dimensions must be adhered to. In this example, one pattern was created for the polygon surface and four patterns for the connecting strands with different orientations. The connecting strands were drawn with 1 point (pt) line thickness $(0.35 \mathrm{~mm})$, which corresponds to one extrusion of the 3D printer. The distance between the connecting strands was also $1 \mathrm{pt}$ so that they do not fuse together. The repeating pattern of the polygon had the size $4 \mathrm{~mm} \times 3.5 \mathrm{~mm}$, the distance between the polygons was $1 \mathrm{pt}$. A frame was drawn around the textile-like surface for the individual strands to adhere to it during the printing process. The line thickness of the frame was $4 \mathrm{pt}$ (cf. Figure 2). Patterns were converted into outlines, the so-called paths, before export. The operation was made easier by recording actions [12]. Several consecutive steps were performed by playing the action. The sketch was exported as an SVG-file for each layer and for each material individually. In this example, 11 SVG files were exported.

\subsection{D modelling}

Blender version 2.78 was used in this study. Each SVG file was imported in Blender and extruded to a three-dimensional object. The extruded object is initially a curve object that must be converted to a mesh model. 3D models were exported individually as STL files. In this example, 11 STL files were exported.

\subsection{Processing in Netfabb}

The Autodesk Netfabb Premium Version 2018 was used to process the STL files. Since Blender does not work with real dimensions, the next step was to scale the exported STL models to their original size. The original size corresponds to the dimensions ( $\mathrm{X}=$ width, $\mathrm{Y}=$ height $)$ in Adobe Illustrator. Additionally, the Z-value was set in Netfabb to $0.15 \mathrm{~mm}$. The Z-value should correspond to the Layer Height (LH) in the settings of the slicer program. Then, all layers were moved to their print position on the Z-axis. With an $\mathrm{LH}$ of $0.15 \mathrm{~mm}$, the position of layer $1(\mathrm{~L} 1)$ is $\mathrm{Z}=0 \mathrm{~mm}, \mathrm{~L} 2 \mathrm{Z}=0.15 \mathrm{~mm}$, $\mathrm{L} 3 \mathrm{Z}=0.3 \mathrm{~mm} \ldots \mathrm{L} 11 \mathrm{Z}=1.5 \mathrm{~mm}$. The layers were exported individually as STL. In this example, 11 STL files were exported.

\subsection{Settings in slicer software}

In this work, the software Simplify3D Version 4.0.0 was used for slicing the $3 \mathrm{D}$ models. Table 1 shows all relevant settings for the printing process. If certain settings are not listed, it can be assumed that the default values of Simplify3D were used.

\section{$2.63 \mathrm{D}$ printers and $3 \mathrm{D}$ printing filaments}

For printing, the PLA and LAY-FOMM 40 materials were used. LAY-FOMM 40 is a micro-porous elastomer with a PVA filler, which will be dissolved in water after the printing and it only then gives the material its elastic properties. Since the material quickly absorbs moisture, the material must be dried before the printing according to the manufacturer's instructions [14]. Both filaments had the diameter of $1.75 \mathrm{~mm}$.

The model was printed with the 3D printer X400. The printer was equipped with two extruders, each with a nozzle of $0.4 \mathrm{~mm}$. PLA was fed to the left extruder, LAY-FOMM 40 to the right extruder. The distance between the print bed and nozzle was $0.15 \mathrm{~mm}$. It was printed directly on the glass plate. The printing time of the 3D model was $2 \mathrm{~h} 29 \mathrm{~min}$. For the models made of more than two different materials (LAY-FOMM 40 plus two colours of PLA), a printer with more than two extruders was required; therefore, the 3D printer CR-10 (1 extruder, $0.4 \mathrm{~mm}$ nozzle) was used in combination with the Palette 2 Pro device. Palette 2 Pro is a device that combines up to four different materials into one filament, enabling multi-material printing with just one extruder [15].

\subsection{Post-processing of printed models}

The print model was removed from the print bed when cold, thus preventing the fine structures from being damaged with a scraper tool. The model was placed in water for 4 hours until the PVA was washed out, with the water being exchanged at least 3 times. In the next step, the model was dyed. To 1 litre of cold water, 6 tablespoons of RIT all-purpose dye (Nakoma Products LLC, Bridgeview, IL, USA) and 1 tablespoon of apple vinegar (Organic apple cider, Publix Supermarkets INC., Lakeland, FL, 
Table 1: Settings for Simplify3D used in this study

\begin{tabular}{|c|c|c|}
\hline Settings & Value & Comments \\
\hline \multicolumn{3}{|l|}{ Extruder settings } \\
\hline Extrusion width & auto & For both tools (extruders) \\
\hline Retraction distance & $1.0 \mathrm{~mm}$ & \\
\hline Retraction vertical lift & $1.0 \mathrm{~mm}$ & \\
\hline \multicolumn{3}{|l|}{ Layer settings } \\
\hline Layer height & $0.15 \mathrm{~mm}$ & \\
\hline First layer height & $100 \%$ & \\
\hline First layer width & $100-120 \%$ & \\
\hline First layer speed & $40 \%$ & \\
\hline \multicolumn{3}{|l|}{ Temperature settings } \\
\hline Tool 0 & $200^{\circ} \mathrm{C}$ & PLA \\
\hline Tool 1 & $220^{\circ} \mathrm{C}$ & LAY-FOMM 40 \\
\hline Heated Bed & $60^{\circ} \mathrm{C}$ & Glass plate \\
\hline \multicolumn{3}{|l|}{ Scripts settings } \\
\hline Tool change script [13] & $\begin{array}{l}\text { G1 Y10 F4000 } \\
\{\text { IF NEWTOOL }=0\} \text { M104 S190 T1 } \\
\{\text { IF NEWTOOL }=0\} \text { M109 S200 T0 } \\
\{\text { IF NEWTOOL }=1\} \text { M104 S170 T0 } \\
\{\text { IF NEWTOOL }=1\} \text { M109 S220 T1 }\end{array}$ & $\begin{array}{l}\text { Go to } \mathrm{Y} 10 \mathrm{~mm} \\
\text { Set T1 to wait temperature } \\
\text { Set T0 to print temperature } \\
\text { Set T0 to wait temperature } \\
\text { Set } \mathrm{T} 1 \text { to print temperature }\end{array}$ \\
\hline \multicolumn{3}{|l|}{ Speed settings } \\
\hline Default printing speed & $2002 \mathrm{~mm} / \mathrm{min}$ & \\
\hline $\mathrm{X} / \mathrm{Y}$ axis movement speed & $3200 \mathrm{~mm} / \mathrm{min}$ & \\
\hline \multicolumn{3}{|l|}{ Other settings } \\
\hline $\begin{array}{l}\text { Tool change retraction } \\
\text { distance }\end{array}$ & $7 \mathrm{~mm}$ & \\
\hline External thin wall type & Allow single extrusion walls & \\
\hline Internal thin wall type & Allow gap fill & \\
\hline Allowed perimeter overlap & $20 \%$ & \\
\hline Endpoint extension distance & $0.9 \mathrm{~mm}$ & \\
\hline
\end{tabular}

USA) were added. The model was left in the dye bath for the next 6 hours and rinsed afterwards in running water. Next, the colour was fixed with RIT ColorStay Dye Fixative (Nakoma Products LLC, Bridgeview, IL, USA). The Color Fixative was sprayed pure onto the model and rinsed out after 1 hour under running water. The coloured model was carefully pressed dry with a paper towel. After the dyeing process, the porous LAY-FOMM 40 material was completely stained, on PLA, the dyeing process had no effect. Then, the model was placed in a water-glycerine solution (10\% glycerine) (Vegetable Glycerin, Earth's Care Natural Products Inc., Long
Beach, CA, USA) for one hour and then dried in the air. Glycerine is a naturally-occurring humectant that attracts and holds water molecules on a surface. It ensures that the LAY-FOMM 40 material does not dry out and retains its flexibility. In the end, the frame of the 3D model was cut off with scissors.

\section{Results and discussion}

By using the new printing method, various repeating patterns were created for the surface of textilelike structures. Furthermore, different effects on the 
properties of textile-like surfaces were documented. Secondly, the surface of textile-like structures was modified with colours in order to meet the designspecific requirements of a textile. In the final step, the printing method was used to print a garment.

The following textile-like surfaces were created based on the new printing method. Different forms of repeating patterns such as polygons (cf. Figure $3 \mathrm{~A}$ ), rectangles (cf. Figure $3 \mathrm{~B}$ ) and floral shapes (cf. Figure 3C) were created and printed from PLA. It was shown that the choice of the pattern influences the properties of the textile-like surface. A patterned surface of polygons $(4 \mathrm{~mm} \times 3.5 \mathrm{~mm}$ each $)$ is showing a different drape than a repeating pattern of rectangles ( $3.3 \mathrm{~mm} \times 3.3 \mathrm{~mm}$ each) (cf. Figures 3D-E). Larger patterns $(23.1 \mathrm{~mm} \times 22.5 \mathrm{~mm}$ each $)$ were also used; the larger the pattern, the more rigid the textile-like surface became (cf. Figure 3F). The size of the repeating pattern also has a large influence on the printing time of the model. The smaller the pattern, the longer the printing process takes. In this study, a repeating pattern of $4 \mathrm{~mm} \times 4 \mathrm{~mm}$ was considered to be a good compromise between surface flexibility and printing time. In further experiments, the limit values should be investigated in order to answer the question which minimum size a repeating pattern could have in order to obtain the greatest possible flexibility of the textile-like surface. On the other hand, the maximum printing speed should be set for the printing method which ensures the same print quality.

The basic structure (connecting strands) was always adapted to different forms of the repeating pattern. Due to the different orientation of connecting strands, it was attempted to take into account the tensile directions acting on a textile surface. The flexibility of the surface could also be influenced by the number of layers and especially by the number of connecting strands. The more connecting strands the structure contains, the more rigid the surface became (cf. Figures $4 \mathrm{~A}-\mathrm{C}$ ) and at the same time, the tensile strength of the structure increased. In this study, a good compromise between flexibility, elasticity and tensile strength of the textile-like surface was perceived with a print model consisting of 11 layers (cf. Figure 4C). Future work will include the determination of mechanical properties such as tensile strength due to the differences in the number of connecting strands, the orientation of connecting strands, printing speed and the value of Extrusion
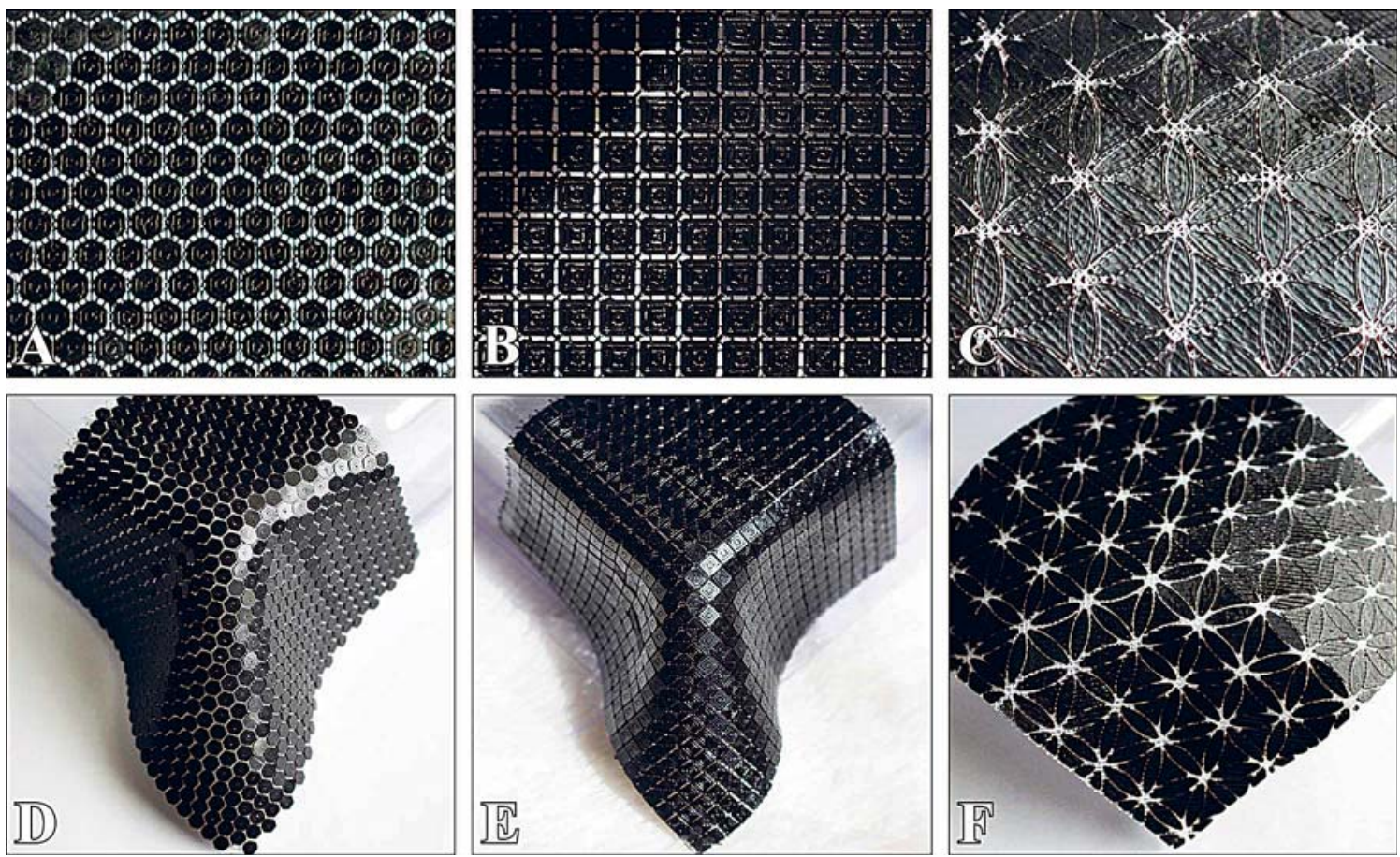

Figure 3: Illustration of different repeating patterns: A) polygon pattern, B) rectangles pattern, C) floral pattern, D) fabric-like drape with polygon pattern, E) fabric-like drape with rectangles pattern, F) drape with big patterns 

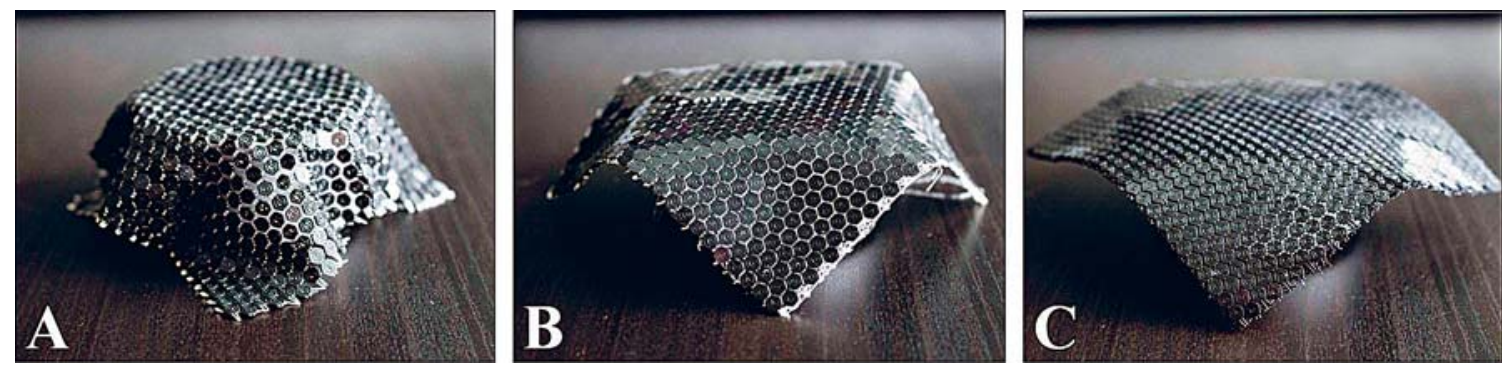

Figure 4: Different flexibilities due to number of layers: A) 5 layers (3 layers PLA, 2 layers LAY-FOMM 40), B) 7 layers (4 layers PLA, 3 layers LAY-FOMM 40), C) 11 layers (6 layers PLA, 5 layers LAY-FOMM 40)

Multiplier (EM). This experiment showed that it is possible to print multi-material textile-like structures by using the FDM technology.

An important aspect of this work was to ensure the wearing comfort of textile-like surfaces. These properties could be ensured by the flexible and elastic printing material LAY-FOMM 40. According to the manufacturer, LAY-FOMM 40 is harmless and food-safe [14]; therefore, four layers of LAY-FOMM 40 were printed on each model to serve as a skin contact surface (cf. Figure 5A). Basically, it is a printed layer of an inner lining, which is also incorporated in conventional clothing. With manual intervention during the printing process on the Z-height of a layer, special effects could be achieved. On the one hand, by reducing the actual Z-height of the last four layers, it was possible to achieve a fusion of these layers, which form a dense surface (cf. Figure 5B). On the other hand, by increasing the Z-height between 7 and 8 layers, it was possible to separate the inner lining and the textilelike surface, which were only held together through the common edge (cf. Figure 5C). In this experiment, it was shown that the garment processing steps, such as attaching an inner lining to a garment, can be implemented in a single printing process.

In the further part of the study, the colour of the textile-like surface was modified in order to meet the design-specific requirements. At first, the repeating pattern was modified with different colours. The different colours were exported as a separate STL file and assigned to different processes in Simplify3D [16]. Figure 6A shows a textile-like surface with a two-colour pattern similar to an all-over print of a textile. In Figure 6B, every single surface was assigned to a different colour, to the so-called houndstooth pattern. The smaller the repeating patterns, the better the resolution of the image. In the next step, a simple image (Logo of University of Central Florida) was transferred onto a textile-like surface (cf. Figure 6C). At the edge of the image, individual polygons were divided into two colour areas. Even though the print became less accurate overall, the result was a clear presentation of the image. For the textile industry, this printing method could mean the elimination of dyeing and printing processes in the textile supply chain.
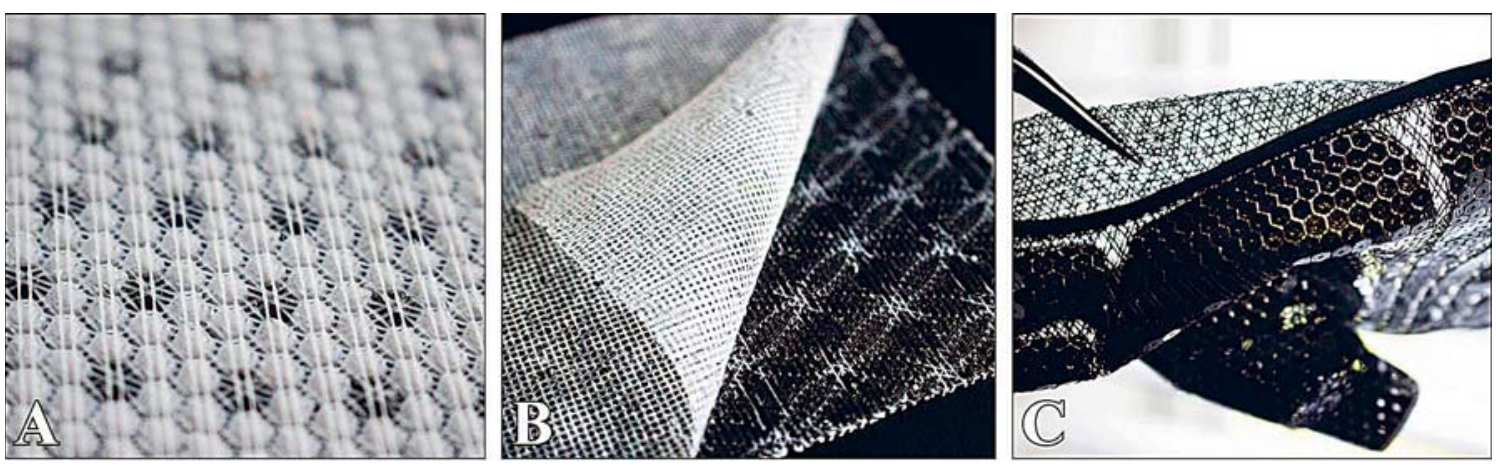

Figure 5: Printed inner lining: A) four layers LAY-FOMM 40 on top of textile-like surface, B) fusion of four layers of LAY-FOMM 40 by reducing Z-height, C) separation of inner lining and textile-like surface by increasing Z-height 

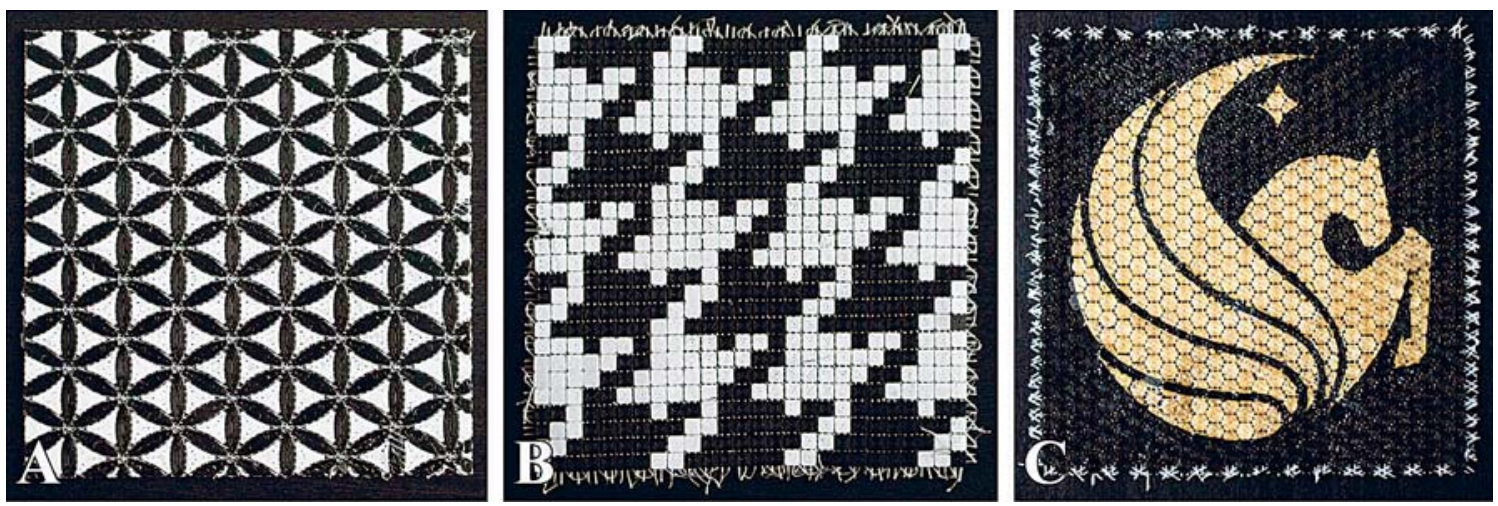

Figure 6: Colour modification of textile-like surfaces: A) two-colour pattern, B) coloured "pixels" to houndstooth pattern, C) transferred UCF Logo on textile-like surface

In the last step of the study, the developed printing method was applied to one application case. In collaboration with a $\mathrm{PhD}$ project at the University of Central Florida in Orlando, a glove with incorporated sensors was printed on the basis of textile-like structures [17]. For the glove, sewing patterns were developed (cf. Figure 7A), which are also used in the textile industry to create garments. It was printed with the 3D printer X400, and the materials PLA and LAY-FOMM 40. Figures 7B-C show the surface design of the glove, the surface was printed partially with polygons, so that the connecting strands (natural colour of LAY-FOMM 40) can be seen inbetween. The printed pattern pieces were posttreated as described above (without dyeing process) and sewn together to form a three-dimensional garment (cf. Figure 7D). In further experiments, it will be worked out how 3D printed textile-like surfaces can be sensibly connected with each other. On the one hand, special joining techniques such
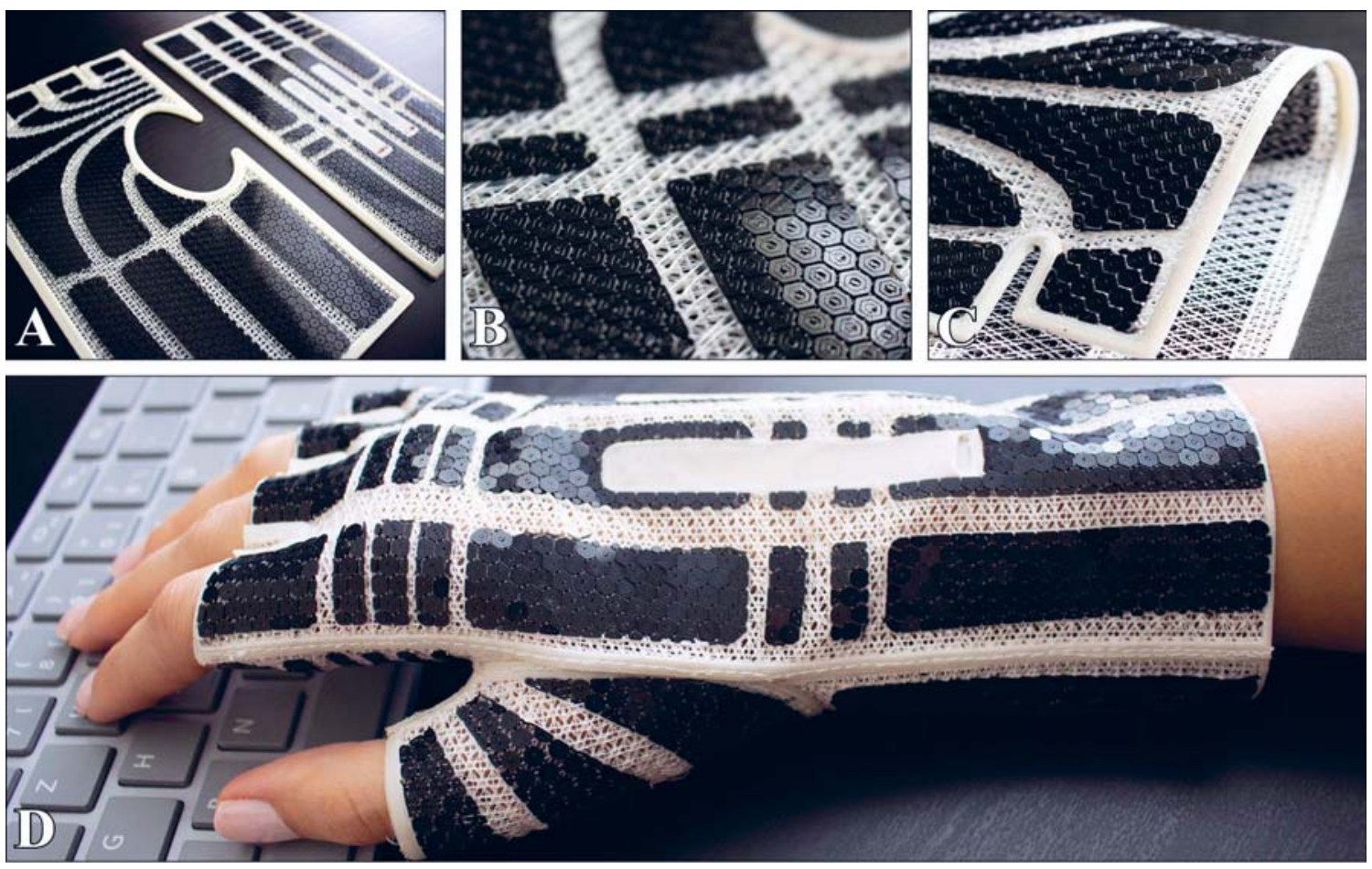

Figure 7: 3D printed glove: A) sewing pattern printed from two materials, B) surface design of glove, C) flexible sewing pattern with inner lining, $D$ ) pattern pieces sewn together to three-dimensional garment 
as ultrasound could be used, whereas on the other hand, 3D printed connections could be developed, which connect textile-like surfaces without a further need for tools. In this experiment, it was shown that clothing patterns can be printed from several materials in one printing process. For the textile industry, this could mean the elimination of the cutting process in the textile supply chain.

\section{Conclusion and outlook}

A new method for printing textile-like surfaces was developed. Several materials were combined in the printing process (FDM) to a flexible coherent structure. On the basis of this printing method, sewing patterns were printed and assembled to a three-dimensional garment. It was shown that production steps of the textile supply chain such as fabric production, dyeing, colour printing, cutting and the application of other components such as inner linings can be implemented in a single printing process. Further developments will focus on improving the printing method and lead to further applications for the textile industry. The results of this study are showing the possibilities of 3D printed textiles, and serve as an inspiration for other researchers and designers to design garments by using the $3 \mathrm{D}$ printing technology.

\section{Acknowledgement}

The author offers her sincerest gratitude to the Prototype Development and 3D Print Lab (PD3D Lab) for giving the opportunity to print all samples as well as for providing the material and support for this research work.

\section{References}

1. ATTARAN, Mohsen. The rise of 3-D printing: The advantages of additive manufacturing over traditional manufacturing. Business Horizons, 2017, 60(5), 677-688, doi: 10.1016/j.bushor. 2017.05.011.

2. Adidas [online]. Adidas breaks the mould with 3D-printed performance footwear. [accessed 5. 7. 2019]. Available on World Wide Web: <https://www.adidas-group.com/en/media/newsarchive/press-releases/2015/adidas-breaksmould-3d-printed-performance-footwear/>.
3. Jewelry [online]. Shapeways [accessed 5. 8. 2019]. Available on World Wide Web: <https:// www.shapeways.com/marketplace/jewelry >.

4. MELNIKOVA, Rimma, EHRMANN, Andrea, FINSTERBUSCH, Karin. 3D printing of textilebased structures by fused deposition modelling (FDM) with different polymer materials. IOP Conference Series: Material Science and Engineering, 2014, 62, doi: 10.1088/1757-899X/ 62/1/012018.

5. SABANTINA, Lilia, KINZEL, Franziska, EHRMANN, Andrea, FINSTERBUSCH, Karin. Combining 3D printed forms with textile structures - mechanical and geometrical properties of multi-material systems. IOP Conference Series: Material Science and Engineering, 2015, 87, doi: 10.1088/1757-899X/87/1/012005.

6. KORGER, Michael, BERGSCHNEIDER, Julia, LUTZ, Mirja, MAHLTIG, Boris, FINSTERBUSCH, Karin, RABE, Maike. Possible applications of 3D printing technology on textile substrates. IOP Conference Series: Material Science and Engineering, 2016, 141(1), doi: 10.1088/ 1757-899X/141/1/012011.

7. GRIMMELSMANN, Nils, KREUZIGER, Mirja, KORGER, Michael, MEISSNER, Hubert, EHRMANN, Andrea. Adhesion of 3D printed material on textile substrates. Rapid Prototyping Journal, 2018, 24(1), 166-170, doi: 10.1108/ RPJ-05-2016-0086.

8. UNGER, Lena, SCHEIDELER, Marvin, MEYER, Pia, HARLAND, Julia, GÖRZEN, Andreas, WORTMANN, Martin, DREYER, Axel, EHRMANN, Andrea. Increasing adhesion of 3D printing on textile fabrics by polymer coating. Tekstilec, 2018, 61(4), 265-271, doi: 10.14502/ Tekstilec2018.61.265-271.

9. KOZIOR, Tomasz, DÖPKE, Christoph, GRIMMELSMANN, Nils, JUHÁSZ JUNGER, Irén, EHRMANN, Andrea. Influence of fabric pretreatment on adhesion of three-dimensional printed material on textile substrates. Advances in Mechanical Engineering, 2018, 10(8), doi: 10. 1177/1687814018792316.

10. RICHTER, Christoph, SCHMÜLLING Stefan, EHRMANN, Andrea, FINSTERBUSCH, Karin. FDM printing of 3D forms with embedded fibrous materials. International Conference on Design, Manufacturing and Mechatronics, 2015, 961-969, doi: 10.1142/9789814730518_0112. 
11. Adobe [online]. Create and edit patterns [accessed 23. 7. 2019]. Available on World Wide Web: <https://helpx.adobe.com/illustrator/using/create-edit-patterns.html>.

12. Adobe [online]. Automation with actions. [accessed 23. 7. 2019]. Available on World Wide Web: <https://helpx.adobe.com/illustrator/using/automation-actions.html>.

13. DocPlayer [online]. X400 German RepRap Dual printing X400V3. Printing successfully with water soluble material [27. 9. 2019]. Available on World Wide Web: <https://docplayer.org/ 53517474-X400-german-reprap-dual-printing$\mathrm{x} 400 \mathrm{v} 3$-printing-successfully-with-water-soluble-material.html>.

14. Matter Hackers [online]. 3D printer filament PORO-LAY LAY-FOMM 40 porous filament -
$1.75 \mathrm{~mm}(0.25 \mathrm{~kg})$ [accessed 16. 6. 2019]. Available on World Wide Web: <https://www. matterhackers.com/store/3d-printer-filament/ poro-lay-lay-fomm-filament-175mm $>$.

15. Mosaic [online]. Palette 2 Pro. Mosaic manufacturing [accessed 18. 7. 2019]. Available on World Wide Web: <https://www.mosaicmfg.com/ products/palette-2?variant $=12502310256734>$.

16. YouTube [online]. Slicing with simplify3d for palette/ palette+ [accessed 5. 6. 2019]. Available on World Wide Web: <https://www.youtube.com/ watch? $\mathrm{v}=$ EydvbCmaKmc\&feature $=$ youtu.be $>$.

17. KIRAN, Kattoju Ravi, UYSAL, Rimma, STUBBS, Jack, LAVIOLA, Joe. Correct me: Detection and correction of wrist extension using electrical muscle stimulation and design of 3D printed flexible glove. $C H I, 2020$, submitted. 